\title{
PATTERNS OF DETECTION AND OPTICAL CORRECTION AMONG OPHTHALMOLOGISTS
}

\author{
Regina de Souza Carvalho, Newton Kara-José, Edméa Rita Temporini, Newton \\ Kara-Junior
}

\begin{abstract}
Carvalho R de S, Kara-José N, Temporini ER, Kara-Junior N. Patterns of ddetection and optical correction among ophthalmologists. Clinics. 2007;62(1):11-6.
\end{abstract}

OBJECTIVE: To verify age of first ophthalmic evaluation and optical prescription along with present optical correction among ophthalmologists of different age groups.

METHODS: A cross-sectional study was conducted with a nonprobabilistic sample $(n=578)$ of ophthalmologists and resident physicians using a self-administered questionnaire.

RESULTS: The first ophthalmologic exam was undergone before age 7 for $33.3 \%$ of the ophthalmologists aged between 23 and 30 years, for $25.8 \%$ of those aged from 31 to 42 , and for $15.8 \%$ of those aged from 43 to 76 years $(P<0.0005)$. The first ophthalmologic exam was undergone at 8 to 22 years of age for $60.7 \%$ of the ophthalmologists aged between 23 and 30 , for $54.9 \%$ of those aged between 31 and 42 , and for $47.4 \%$ of those aged from 43 to 76 years of age. Use of the first optical prescription (eyeglasses) between 0 and 7 years was reported by 10.0\%, from 8 to 20 years of age by 59.6\%, from 21 to 40 years by 18.1\%, and 41 years or older by $12.3 \%$. Present use of optical correction was reported by $69.0 \%$. Concerning type of corrective device chosen, $63.7 \%$ wore only eyeglasses, $29.8 \%$ wore eyeglasses and contact lenses, and $6.5 \%$ wore contact lenses only.

CONCLUSION: Among the sample of opthalmologists, the first ophthalmic evaluation and corresponding optical correction usually occurred relatively late ( 8 to 20 years of age). However, in the younger group of ophthalmologists, there was a highly significant increase in the number of subjects who had undergone an ophthalmologic exam before age 7. Eyeglasses were reported as the correction of choice by those in all age groups.

KEYWORDS: Ophthalmic evaluation, optical correction, eyeglasses, contact lenses.

\section{INTRODUCTION}

Optical health promotion is centered on developing and preserving visual capacity, allowing the individual better quality of life and participation in society. ${ }^{1}$

Since vision is a main contact pathway with the external world, any abnormality in its functioning may become a disabling obstacle to the individual's normal development. $^{2}$

Ophthalmology Clinic, São Paulo University Medical School - São Paulo/ SP, Brazil.

Email: regina-sc@uol.com.br

Received for publication on August 29, 2006.

Accepted for publication on October 09, 2006.
The causes of visual capacity loss are numerous and relate to biological, social, and environmental factors. ${ }^{3} \mathrm{Sev}$ eral factors contribute to the final refraction power, and the hemitropic eye is a rare finding.

In Brazil, Costa et $\mathrm{al}^{4}$ have signaled the need for corrective eyeglasses in $6.33 \%$ of a preschool population.

Kara José et $\mathrm{al}^{2}$ have reported only $14.7 \%$ of hemitropic subjects in a school-age population. However, when we consider the indication for optical correction, the proportion of subjects in need of it is approximately $6.0 \%$ at 7 years of age, $65.0 \%$ between 18 and 40 years, and there is a trend towards $100.0 \%$ after 40 . The importance of the lack of optical correction has been pointed out by Arieta et $\mathrm{al}^{5}$ as the major cause of reduced visual capacity among people above 50 . 
Optical correction of refractive errors, due to its relevance, has been considered a priority in the "Vision-20/ 20" proposal, from the World Health Organization. ${ }^{6}$ Visual problems may be detected early, and they require appropriate identification and treatment measures. ${ }^{7,8}$

In Brazil, the Brazilian Ophthalmology Council [Conselho Brasileiro de Oftalmologia (CBO)] has proposed the routine evaluation of every child of school age at the start of elementary school, ie, at the age of $7 .^{9}$ In addition, it has recommended that every child who presents a sign or symptom of optical abnormality or a family history of ocular problems be evaluated as early as possible. The "Eye in Eye" National Visual Rehab Campaign [Campanha Nacional de Reabilitação Visual "Olho no Olho"] recommended assistance to school-age children regularly enrolled in the first grade of the public elementary school system, based on the assumption that the first school year requires from the child a new perception of the world and adequate resources to develop his/her motor, intellectual, and social skills. In addition to the fact that this is an appropriate age for the $1^{\text {ST }}$ optical evaluation, the children who regularly attend school are easy to access for evaluation. ${ }^{8,9}$

It is well known that approximately $15.0 \%$ of schoolage children require optical correction, around $4.0 \%$ are amblyopic, and $25.0 \%$ require some form of ophthalmic care; however, the children's visual problems may go unnoticed due to a lack of awareness or absence of signs and/ or complaints. ${ }^{9}$

It is essential to correctly determine the distribution of refractive errors and the percentage of people who require and receive care in different population cohorts to support the implementation of resources to control these conditions. Epidemiological surveys and those related to peoples' behavior concerning identification of disorders and optical correction become decisive factors for the implementation of ocular health care programs.

Several strategies have been proposed to reach these goals, among which is the conduct of research aimed at assessing the magnitude of the problem and proposing feasible approaches. ${ }^{10}$

In Brazil, there are no studies concerning the age at the time of the first ophthalmic evaluation or about the age when the first optical prescription (eyeglasses) was used. With the objective of obtaining data on the ophthalmic evaluation coverage in selected population groups to serve as a basis for future comparisons, this survey was conducted among ophthalmologists attending a scientific event. The goal was to determine the age distribution over the past decades of the time of first ophthalmic evaluation, first ophthalmic prescription, and type of current optical correction among the aforementioned group of ophthalmologists. This is part of an overall strategy to define conditions under which Brazilian Ophtalmologists are expected to proceed. ${ }^{11,12}$

\section{METHODS}

A cross-sectional study was conducted among ophthalmologists, resident physicians, and trainees in ophthalmology who attended a scientific event held in Curitiba, Brazil, in 2002.

The research project was approved by the Ethics Committee of the Hospital das Clínicas, University of São Paulo Medical School.

We chose to apply a structured questionnaire that was distributed to a nonprobabilistic sample. Considering that this was a self-administered questionnaire, the " $n$ " on the tables presents some variation depending on the supplied answers. The significance level of 0.05 was used for checking associations.

\section{RESULTS}

The sample included 578 ophthalmologists, with $78.3 \%$ in the age group between 43 and 76 years. The mean age was 39.1 years (standard deviation of 11.8 years). The number of entered opthalmologists in the varsious age groups was significantly different $(P<0.0001)$ (Table 1$)$.

Table 1 - Sample description by age and gender

\begin{tabular}{lcccccc}
\hline & \multicolumn{4}{c}{ Gender* } & \multicolumn{3}{c}{ Total } \\
Age (years) & \multicolumn{2}{c}{ Female } & \multicolumn{2}{c}{ Male } & \multicolumn{2}{c}{ To } \\
& $\mathrm{n}$ & $\%$ & $\mathrm{n}$ & $\%$ & $\mathrm{n}$ & $\%$ \\
\hline 23 to 30 & 72 & 40.4 & 106 & 59.6 & 478 & 100.0 \\
31 to 42 & 73 & 38.4 & 117 & 61.6 & 190 & 100.0 \\
43 to 76 & 43 & 21.7 & 155 & 78.3 & 198 & 100.0 \\
\hline
\end{tabular}

mean $=39.1$ uears, $\mathrm{SD}=11.8$ years

$\mathrm{X}^{2}=18.321 \quad \mathrm{DF}=2 \quad P<0.0001$

* no gender reported for 12 subjects

Among the ophthalmologists, $31.7 \%$ were female and $68.3 \%$ were male. Among resident physicians, $37.8 \%$ were female and $62.2 \%$ were male (Table 2).

Table 3 presents the answers given when the questions concerned the undergoing of an ophthalmic evaluation (97.2\%) and the present use of optical correction (69.0\%); $2.8 \%$ had never undergone an ophthalmic evaluation.

Among those who used corrective lenses, $63.7 \%$ used only eyeglasses and $29.8 \%$ alternated the use of eyeglasses and contact lenses, whereas $6.5 \%$ used only contact lenses (Figure 1). 
Table 2 - Professional category and gender

\begin{tabular}{lcccccc}
\hline & \multicolumn{3}{c}{ Gender } & & \multicolumn{2}{c}{ Total* } \\
Professional & \multicolumn{2}{c}{ Female } & \multicolumn{2}{c}{ Male } & \multicolumn{2}{c}{ Toteg } \\
category & $\mathrm{n}$ & $\%$ & $\mathrm{n}$ & $\%$ & $\mathrm{n}$ & $\%$ \\
\hline Ophthalmologist & 138 & 31.7 & 297 & 68.3 & 435 & 100.0 \\
$\begin{array}{l}\text { Resident } \\
\text { physician/Trainee }\end{array}$ & 48 & 37.8 & 79 & 62.2 & 127 & 100.0 \\
\hline
\end{tabular}

$-\mathrm{N}=562 ; 16$ subkects did not answer

$\mathrm{X}^{2}=2.145 \quad \mathrm{DF}=2 \quad P=0.342$

Table 3 - Aspects of the ophthalmic evaluation

\begin{tabular}{lcc}
\hline Aspects & $\mathrm{n}$ & $\%$ \\
\hline $\begin{array}{l}\text { Had undergone } \\
\text { ophthalmic evaluation }\end{array}$ & 562 & 97.2 \\
$\begin{array}{l}\text { Had never undergone } \\
\text { ophthalmic evaluation }\end{array}$ & 16 & 2.8 \\
\begin{tabular}{l} 
Currently use correction \\
\hline
\end{tabular} & 399 & 69.0 \\
\hline
\end{tabular}

$\mathrm{N}=578$

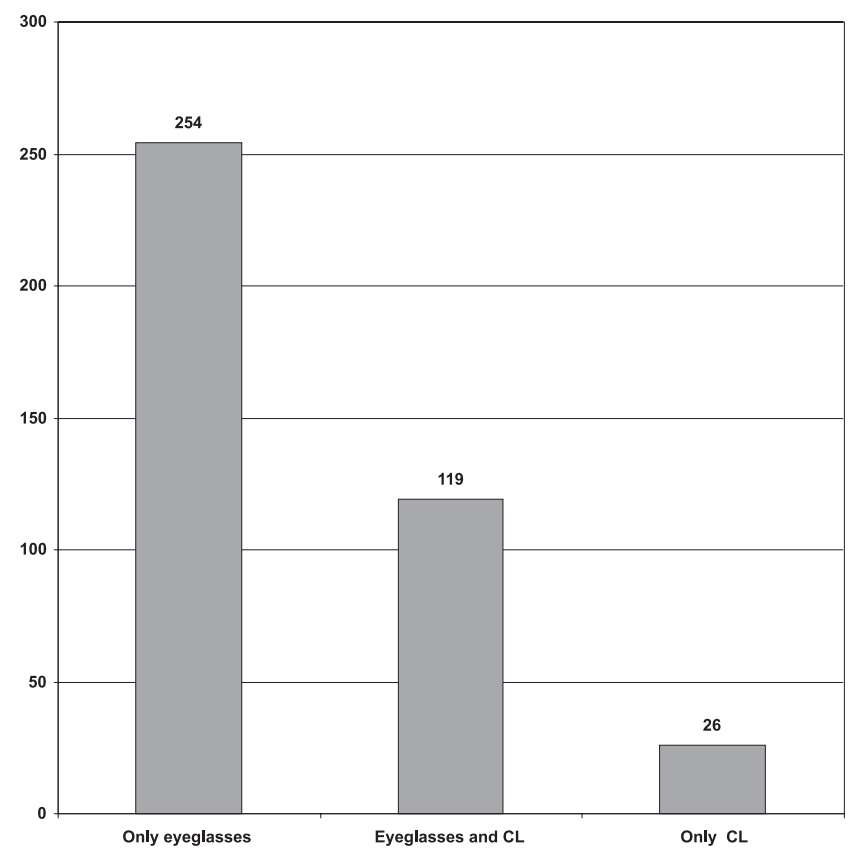

Figure 1 - Type of present optical correction $(n=399$
The percentages of opthalmologists undergoing the first ophthalmologic exam by age 7 were as follows: $33.3 \%$ in the age range of 23 to 30 years, $25.8 \%$ of those from 31 to 42 years, and $15.8 \%$ from 43 to 76 years of age. The percentages of opthalmologists undergoing the first ophthalmologic exam between 8 and 20 years of age were as follows: $60.7 \%$ from 23 to 30 years, $54.9 \%$ from 31 to 42 years, and $47.4 \%$ between 43 and 76 years of age. The percentages of opthalmologists undergoing the first ophthalmologic exam between 21 and 40 years of age were as follows: $6 \%$ of those from 23 to 30 years, $19.2 \%$ from 31 to 42 years, and $31.1 \%$ from 43 to 76 years of age. The first ophthalmologic exam was performed above age 41 only in $5.6 \%$ of the ophthalmologists from 43 to 76 years of age (Table 4). (Fisher exact test $P<0.0005$ ).

It should be noted that 16 subjects failed to answer, and 16 had never undergone an ophthalmic evaluation.

The percentages of ophthalmologists by age group receiving their first optical prescription (eyeglasses) were as follows: from 0 to 7 years of age, $10.0 \%$; from 8 to 20 , $59.6 \%$; from 21 to $40,18.1 \%$; and from 41 years of age and older, $12.3 \%$. From the 47 subjects (10.0\%) who reported receiving an optical prescription between ages 0 and 7 years of age, $20(42.6 \%)$ reported receiving a prescription at age 7 , which is $3.5 \%$ of the whole sample in the present study $(\mathrm{n}=578)$.

Cumulatively, $87.7 \%$ of the opthalmologists started using optical correction before age 40 .

\section{DISCUSSION}

There is no consensus about the feasible and recommended age of the first ophthalmic evaluation. In some countries, it is recommended that a brief examination be performed with every newborn baby in the nursery; other countries recommend that examinations be performed from age 4 or at 7 years, at school admittance. ${ }^{13}$

Studies in different age groups concerning the need for optical correction are not present in the literature.

The current study population, consisting of graduated ophthalmologists, was selected based on the presupposition

Table 4 - Age range and age at first ophthalmic evaluation among ophthalmologists

\begin{tabular}{|c|c|c|c|c|c|c|c|c|}
\hline \multirow{3}{*}{$\begin{array}{l}\text { Age range of } \\
\text { ophthalmologist }\end{array}$} & \multicolumn{8}{|c|}{ Age at first examination } \\
\hline & \multicolumn{2}{|c|}{ Before 7 years } & \multicolumn{2}{|c|}{ 8-20 years } & \multicolumn{2}{|c|}{$21-40$ years } & \multicolumn{2}{|c|}{41 years or more } \\
\hline & $\mathrm{n}$ & $\%$ & $\mathrm{n}$ & $\%$ & $\mathrm{n}$ & $\%$ & $\mathrm{n}$ & $\%$ \\
\hline 23 - 30 years & 56 & 33.3 & 102 & 60.7 & 10 & 6.0 & 0 & 0 \\
\hline 31 - 42 years & 47 & 25.8 & 100 & 54.9 & 35 & 19.2 & 0 & 0 \\
\hline $43-76$ years & 31 & 15.8 & 93 & 47.4 & 61 & 31.1 & 11 & 5.6 \\
\hline Total & 134 & 24.5 & 295 & 54.0 & 106 & 19.4 & 11 & 2.0 \\
\hline
\end{tabular}

$\mathrm{N}=546^{*} ; * 16$ subjects had never undergone an evaluation and 16 subjects did not answer. Fischer exact test $P<0.0005$ 
Table 5 - Age of first optical prescription (eyeglasses)

\begin{tabular}{lccc}
\hline $\begin{array}{l}\text { Age of first } \\
\text { prescriptionm (years) }\end{array}$ & $\mathrm{n}$ & $\%$ & $\%$ cummulative \\
\hline 0 to $7 * *$ & 47 & 10.0 & 10.0 \\
8 to 20 & 280 & 59.6 & 69.6 \\
21 to 40 & 85 & 18.1 & 87.7 \\
41 and above & 58 & 12.3 & 100.0 \\
Total & 470 & 100.0 & \\
\hline
\end{tabular}

* 54 subjects left blank, 47 subjects never had an optical prescription, and 7 subjects said they did not know.

** 20 subjects $(42.6 \%)$ reported prescription at age 7 .

of a higher probability of obtaining reliable data.

Among the participants in this study, male ophthalmologists older than 40 were predominant; the differences between gender and age groups were significant.

The Brazilian Council of Ophthalmology (CBO) and most studies stress the need for the ophthalmologic exam to be performed in children before age 7 . Although the optimal age is 4 years, the existing barriers and the need for optimizing efforts and resources lead most authors to consider as satisfactory the practice of having all children examined around age 7 . The results of this study show an increase in the rate of examination by age 7 among the subjects aged 23 to 30 years, as compared to those aged 31 to 42 and 43 to 76 years. This trend towards an increased number of ophthalmologic exams before age 7 should be reflected in an even larger coverage at present. The awareness about the need to carry out the examination is probably due to the growing amount of counseling provided to parents from pediatricians and ophthalmologists. ${ }^{14}$ The fact that middle- and upper middle-class schools have started to ask for visual and hearing assessments before the child is considered for admission also contributes to increase the detection rate of ocular disorders in childhood. The trend for earlier ophthalmologic exams in recent years is reflected in this study, since $94.0 \%$ of the ophthalmologists aged 23 to 30 , ie, the younger subjects, had undergone an ophthalmologic exam before age 20, whereas $80.7 \%$ of those aged 31 to 42 and only in $63.2 \%$ of those aged 43 to 76 years had received exams by age 20 .

Perhaps because the period from 8 to 20 years is coincident with school years, most people are able to perceive signs and symptoms indicating the need for an ophthalmic evaluation, such as asthenopy and visual difficulties. ${ }^{15}$ These disorders cause complaints that lead the subject or his/her responsible guardian to seek specialized care.

For each individual patient, the examination should be carried out as early as possible; however, from the public health standpoint, it is advisable to assess the relationships of cost, benefit, and available resources before making decisions on new and/or priority issues. The project of performing an ophthalmic evaluation before age 7 has some specific barriers, such as difficulty accessing of the target population, longer and harder ophthalmic evaluation due to the lack of cooperation from the child, lower percentage of required prescriptions, higher probability of errors, lower adherence to the use of lenses, higher proportion of loss and damage of the eyeglasses, and quickly changing refraction power with multiple re-examinations required at intervals as short as 6 months.

The projects that recommend examination at age 7 when the child starts elementary school present some advantages, such as easy identification of the target subjects at school; help from the teacher in detecting visual problems; easier examination; higher percentage of subjects who benefit; increased adherence and level of care with the eyeglasses, since their usefulness is perceived; and annual returns, allowing continued access for re-examination. In this age group, public health care measures should be focused on facilitating access to the examination and availability of optical correction as well as replacement of damaged eyeglasses.

Between 18 and 40 years of age, Minguini et $\mathrm{al}^{16}$ have reported the use of optical correction by $49.5 \%$ of the employees and $56.7 \%$ of the students at the University of Campinas, which reinforces the assumption that the two groups have easily recognized their visual disorders and had easy access to the ophthalmic evaluation. A study conducted in the United States has pointed out that $46 \%$ of the subjects between 18 and 44 years used optical correction. ${ }^{17}$

Bicharra-Pinto*, in the "Eye in Eye" project conducted in Rio de Janeiro (Brazil), has noted a first-call response of only $37 \%$ among screened school children age 7 with an additional $14 \%$ on the second call. In spite of the fact that the examination was performed at no cost to the subject, included free eyeglasses, and was, in addition, conducted close to the child's living place, there was a $49 \%$ rate of absence to scheduled visits, possibly because of the small number of available ophtalmologists. This high rate of missed appointments was likely caused by the lack of awareness about the need to use eyeglasses in this poor population. However, it is also important to take into account the child's potential refusal to consider wearing eyeglasses, which may influence the parents' decision not to take their child to consultation.

Kara-José et al, ${ }^{2}$ in a study conducted with a school-

* Bicharra - Pinto , R. Personal communication, 2004 
age population $(n=1364)$ from public schools, have observed $10.5 \%$ of cases of refractive errors and need for optical correction at age 7. Macchiaverni Filho et al, ${ }^{18}$ examining 564 school-age children between 7 and 15 years in the town of Paulínia (SP), observed the need for optical correction in $9.75 \%$ of the children. Both studies presented similar percentages to those observed in the present study $(10.0 \%)$. It is important to note that there was a change in the approach to prescribing optical correction after the "Eye in Eye" project (2000), where refractive errors of up to 3 positive spherical diopters, 0.75 negative spherical diopters, and astigmatism of 0.5 cylindrical diopters had no prescription in the majority of cases. Following these new prescription standards, the percentage of optical prescriptions (eyeglasses) has ranged from 3.3 to $6 \% .^{20}$

From 0 to 6 years, the cost-effectiveness of the optical prescription is low, but it increases with age. The results of this study have shown that $59.6 \%$ of the subjects had an optical prescription between 8 and 20 years, although it was not an objective of this study to qualify the time of the optical prescription as late or not.

After age 40, the major cause of decrease in visual acuity is refractive errors; from this age on, there is a trend towards $100 \%$ of the population requiring the use of eyeglasses. In this age group, people are able to perceive their deficiencies, and the main reason for leaving the problem unsolved is a difficulty of access to appropriate care. ${ }^{5}$

The Cataract Project and the "Eye in Eye" Project are examples of actions that have shown the result of successful strategies to facilitate access to the treatment of ocular disorders, focused on the age groups mentioned above..$^{5,9}$
The access to an ophthalmic evaluation is a relevant consideration. In this study, only 16 subjects had never undergone an ophthalmic evaluation.

From the 578 subjects, the majority (69.0\%) use optical correction at present. There is a worldwide tendency towards adaptation to contact lenses. With the appearance of disposable lenses, many users who formerly presented ophthalmic problems with daily-use lenses have solved these problems simply by changing the type of lenses. In addition, advances have been made in the correction of astigmatism with daily use and disposable toric lenses and in new materials for correction of the keratocone.

The results obtained in the present study have shown, however, that most of those who answered the questionnaire $(63.6 \%)$ used only eyeglasses, while some of them $(29.8 \%)$ alternated the use of eyeglasses and contact lenses; very few $(6.5 \%)$ used exclusively contact lenses.

Since we have only evaluated ophthalmologists in this survey, we have taken for granted the reliability of the answers concerning the time of the first examination, prescription, and use of optical correction. Therefore, even considering the growth of the contact lens market, there was a generalized preference for the use of eyeglasses.

The results obtained in this survey and their comparison with the available literature demonstrates the need for further studies on the actual status of refractive error correction and possible barriers to it. Such data should provide valuable information for the development of projects that aim at implementing optical correction, and as a result, provide a better quality of life for people who suffer from refractive errors.

\section{RESUMO}

Carvalho R de S, Kara-José N, Temporini ER, Kara-Junior N. Detecção e uso de correção óptica entre Oftalmologistas. Clinics. 2007;62(1):11-6.

OBJETIVO: Verificar em oftalmologistas de diferentes faixas etárias a idade do primeiro exame oftalmológico, dos primeiros óculos e tipos e correlação óptica em uso, a fim de substituir estudos sobre a evolução dos cuidados oftalmológicos nas últimas décadas.

MÉTODOS: Foi realizado estudo transversal em amostra prontamente acessível formada por oftalmologistas e residentes $(n=578)$, por meio da aplicação de questionário.
RESULTADOS: Submeteram-se ao primeiro exame oftalmológico até os 7 anos de idade, 33,3\% dos oftalmologistas na faixa etária de 23 a 30 anos; 25,8\% na faixa etária de 31 a 42 anos e 15,8\% de 43 a 76 anos (teste exato de Fischer $\mathrm{P}<0,0005)$. $\mathrm{O}$ primeiro exame oftalmológico ocorreu entre 8 e 20 anos de idade em 60,7\% dos oftalmologistas na faixa etária de 23 a 30 anos; 54,9\% na faixa etária de 31 a 42 anos e 47,4\% na de 43 a 76 anos. Manifestaram terem usado os primeiros óculos entre 0 e 7 anos $10,0 \%$, entre 8 e 20 anos 59,6\%, entre 21 e 40, 18,1\%; e de 41 anos ou mais, 12,3\%. Dos 69,0\% que mencionaram uso de correção óptica, 63,7\% usavam apenas óculos, 
$29,8 \%$ intercalavam o uso de óculos e de lentes de contato e $6,5 \%$ usavam apenas lentes de contato.

CONCLUSÕES: A época do primeiro exame oftalmológico e da correção óptica ocorreu tardiamente (entre 8 e 20 anos). Porém na faixa etária mais jovem houve um aumento altamente significativo dos indivíduos submetidos a exeme oftalmológico até os 7 anos de idade. Registrouse preferência por uso de óculos em todos os grupos etários.

UNITERMOS: Exame oftalmológico. Correção óptica. Óculos. Lentes de contato.

\section{REFERENCES}

1. Temporini, ER. Promoção da saúde ocular, Arq Bras Oftal. 1999,62:824.

2. Kara-José N, Holzchuh N, Temporini ER. Vícios de refração em escolares da cidade de São Paulo, Brasil. Bol Of. Sanit Panam. 1984;96:326-32.

3. Verdaguer TJ. One world, one voice, one vision. Arq Bras Oftal. 1998,61:5-6

4. Costa M N, et al. Estudo da incidência de ambliopia, estrabismo e anisometropia em pré-escolares. Arq Bras Oftal. 1979;42:249-52.

5. Arieta EL, Delgado NM, Jose NK, Temporini ER, Alves MR, Filho D, et al. Refractive errors and cataract as causes of visual impairment in Brazil. Ophthal Epidem. 2003;10:15-22.

6. Dandona, R; Dandona, L. Refractive error blindness, Bull World Hlth Organ. 2001,79:237-43.

7. Resnikoff S, Pararajasegaram R.Blindness prevention programmes: past, present and future, Bull.World Hlth Organ. 2001;79:222-6.

8. Temporini ER. Prevenção de problemas visuais de escolares: conduta de professores do sistema de ensino do Estado de São Paulo, Brasil, Rev Bras Saúde Esc. 1990;1:68-75.

9. Kara-José N, Alves MRA. Manual de Orientação ao professor. Campanha Nacional de Reabilitação Visual "Olho no Olho", 2001. MEC/FNDE São Paulo, 2002.

10. Temporini ER, Kara-José N. Níveis de prevenção de problemas oftalmológicos, Arq Bras Oftal. 1995;58:189-92.

11. Avakian A, Temporini ER, Kara-José N. Second eye cataract surgery: Perceptions of a population assisted at a university hospital. Clinics. 2005;60:401-406.
12. Oliveira R de SC de S, Temporini ER, Kara-José N, Carricondo PC, Kara-José AC. Perceptions of patients about cataract. Clinics. 2005;60:455-460

13. Köhler L. \& Stigmar G. Visual disorders in 7-year-old children with and without previous vision screening, Acta Pediatr Scand. 1978;67:3737 .

14. Kara-José N. O papel do pediatra na oftalmologia preventiva. Rev. Clin Pediatr. 1980;5:5-6

15. Armond J, Temporini ER, Alves MR. Promoção da saúde ocular na escola: percepções de professores sobre erros de refração. Arq Bras Oftal. 2001;64-5:395-400.

16. Minguini N, Coelho RP, Serpa JF, Kara-José N, Holzchuh N Características do uso dos óculos e lente de contato em uma comunidade universitária. Arq Bras Oftal. 1994;57:126-8

17. Michaels DD. Indications for prescribing spectacles. Surv Opthalmol 1981;26:55-74

18. Macchiaverni FN, Kara-José N, Rueda G, Pereira VL, Costa MN et al. Levantamento oftalmológico em escolares de primeira a quarta séries do primeiro grau na cidade de Paulínia, São Paulo. Arq Bra. Oftal. 1979;42:289-94.

19. Castro RS. Avaliação de uso de óculos por escolares da primeira série do ensino fundamental, Limeira 2002. PhD thesis presented to the State University of Campinas Medical School, in 2002.

20. Kara-José N, Gonçalves ER, Carvalho RS. "Olho no Olho - Campanha Nacional de Prevenção à Cegueira e Reabilitação Visual do Escolar”; Cultura Médica, Rio de Janeiro. 2006:25-38;165-6. 